AKADEMIKA

JURNAL ILMIAH UMGO

\title{
EVALUASI KOMPETENSI PROFESIONAL GURU DALAM MENGELOLA PEMBELAJARAN IPA DI SD MUHAMMADIYAH SE KABUPATEN GORONTALO
}

\author{
Yulanti S. Mooduto \\ Program Studi PGSD, Universitas Muhammadiyah Gorontalo \\ e-mail: yulantimooduto@umgo.ac.id
}

\begin{abstract}
This Article Journal is meant to find out: (1) Teacher Professional Competence is compiling Learning - learning.(2) Teacher Professional Competence in implementing the learning process of science and learning. (3) Teacher Professional Competence in implementing the learning Assesmen of science. This study was carried out at Muhammadiyah Elementary in the Gorontalo district. The Method used is a descriptive qualitative research method that includes performance planning and learning assessments with data acquisition trough observation interviews and documentation. Studies show that: (1). The teacher.s professional competence of putting together new set of learning for science at Muhammadiyah elementary and gorontalo discrict have been generally good for only a few teaher's who plan to learn less. (2). The teacher.s professional competence in performing the learning in this case in under optimal quality of class management. There for, efforts in the quality of learning are required. (3). The teahers profesionallcompetence of assessing learning in general is lacking and $n$ eeds improvement. There are still many teacher who are less than optimal at executing judgment.
\end{abstract}

Keywords: Professional; Teacher competence; IPA 


\begin{abstract}
Abstrak
Artikel ini bertujuan untuk mengetahui: (1) kompetensi profesional guru dalam penyusunan perencanaan pembelajaran IPA, (2) kompetensi profesional guru dalam melaksanakan proses pembelajaran IPA dan (3) kompetensi profesional guru dalam melaksanakan penilaian pembelajaran IPA. Penelitian ini dilaksanakan di SD Muhammadiyah se Kabupaten Gorontalo, Metode yang digunakan adalah metode penelitian kualitatif yang deskriptif yang meliputi perencanaan, pelaksanaan dan penilaian pembelajaran dengan perolehan data melalui wawancara, observasi dan dokumentasi. Hasil penelitian menunjukkan bahwa: (1)kompetensi profesional guru dalam menyusun perencanaan pembelajaran IPA di SD Muhammadiyah se Kabupaten Gorontalo secara umum sudah baik. Hanya pada beberapa orang guru yang kurang dalam merencanakan pembelajaran, (2) kompetensi profesional guru dalam melaksanakan pembelajaran yang dalam hal ini adalah kualitas pengelolaan kelas masih kurang optimal. Oleh sebab itu, perlu adanya upaya-upaya perbaikan untuk peningkatan mutu pembelajaran dan (3) kompetensi profesional guru dalam menilai pembelajaran secara umum masih kurang dan butuh perbaikan. Masih banyak guru yang kurang optimal dalam melaksanakan penilaian.
\end{abstract}

Kata Kunci: Profesional; Kompetensi Guru; IPA

\section{PENDAHULUAN}

Salah satu unsur pendidikan yang dituntut peran serta pendidikan yang besar dalam pembentukan dan pengembangan manusia Indonesia seutuhnya antara lain adalah guru. Sebagai ujung tombak terbesar dalam pendidikan guru merupakan orang yang dipandang memiliki kompetensi untuk membimbing dan mendidik anak, memiliki budi pekerti, serta kepribadian yang patut untuk diteladani.

Mengingat faktor kinerja guru merupakan salah satu faktor yang sangat menentukan bagi keberhasilan program pendidikan maka pemerintah telah melalukan berbagai upaya antara lain mengembangkan sistem pembinaan profesional sesuai dengan kebutuhan guru itu sendiri, yaitu usaha dalam meningkatkan pengetahuan, 
kecakapan keterampilan, serta peningkatan kinerja guru melalui penataran, pendidikan dan latihan, supervisi dan bantuan profesional dari kepala sekolah dan pengawas atau bantuan profesional antara semua teman sejawat, kelompok kerja guru (KKG), yang dilaksanakan secara bertahap dan berkelanjutan.

Kondisi di lapangan menunjukkan lain, dimana masih banyak tenaga pendidik (guru) yang belum mampu menunjukkan profesionalisme yang memadai. Hal ini disebabkan antara lain karena masih banyak guru yang tidak mampu mengelola proses pembelajaran dengan baik, kepala sekolah tidak berusaha menegakkan disiplin dalam melaksanakan tugas, datang dan pulang tidak sesuai dengan waktu yang ditetapkan.

\section{Mencermati berbagai upaya} tersebut, maka dapat dikatakan bahwa kompetensi profesional guru khususnya pada pembelajaran IPA di SD Muhammadiyah se-Kabupaten

Gorontalo masih perlu ditingkatkan dan dibangkitkan melalui berbagai kegiatan pembinaan profesional. Kondisi ini dapat dibuktikan dengan adanya gejalagejala sebagai berikut: (1) masih adanya sejumlah guru yang belum memiliki wawasan dan kemampuan dalam hal merencanakan program, melaksanakan, mengevaluasi serta melakukan penelitian hasil belajar, (2) masih adanya sejumlah guru kurang memiliki inisiatif dan kreatifitas dalam bekerja mengembangkan wawasan pengetahuannya, (3) masih adanya sejumlah guru yang telah mengikuti pengembangan dan pembinaan profesional melalui pendidikan dan pelatihan tetapi belum dapat mensosialisasikan, menyajikan, terlebih menerapkan materi yang diperoleh dari pelatihan dalam pelaksanaan tugasnya, (4) masih adanya sejumlah guru yang kurang merasa bangga bahkan kurang menghargai profesinya sebagai guru sehingga tidak bergairah untuk mengembangkan profesinya tersebut.

Berdasarkan kondisi seperti yang dikemukakan di atas, maka prestasi yang dicapai oleh peserta didik di SD Muhammadiyah se-Kabupaten Gorontalo khususnya mata pelajaran IPA pada Evaluasi Akhir Nasional masih rendah. Hal ini dipengaruhi oleh berbagai faktor sebagaimana dikemukakan di atas, dan faktor lainnya seperti kompetensi profesional guru 
belum berkembang secara optimal.Berdasarkan uraian di atas, maka peneliti tertarik untuk meneliti dan membahas masalah dengan judul "Evaluasi Kompetensi Profesional Guru dalam Mengelola Pembelajaran IPAdi SD Muhammadiyah se-Kabupaten Gorontalo Gorontalo".

\section{METODE PENELITIAN}

Penelitian ini dilakukan di SD Muhammadiyah Se Kabupaten Gorontalo.

Lokasi penelitian SD Muhammadiyah SeKabupaten Gorontalo dipilih karena telah melaksanakan proses pembelajaran secara konvensional sebagaimana sekolah-sekolah lainnya. Sementara, evaluasi terhadap kompetensi guru dalam proses pembelajaran belum dilaksanakan secara optimal. Walaupun evaluasi tersebut sudah dilaksanakan tetapi belum menyangkut keseluruhan aspek dalam pembelajaran.Penelitian ini menggunakan metode penelitian kualitatif yang deskriptif yang meliputi perencanaan, pelaksanaan dan penilaian pembelajaran.
Penelitian kualitatif ini diarahkan pada perencanaan, pelaksanaan dan peniaian kompetensi guru IPA dalam proses pembelajaran. Dengan demikian data yang dikumpulkan akan dianalisi dengan pendekatan induktif/deduktif. Hal ini dilakukankarena berpeluang cukup tinggi untuk menentukan nilai dari sesuatu atas dasar tolok ukur (kriteria) yang telah ditentukan.

\section{Desain Penelitian}

John W.Creswell (2003: 5), mengemukakan bahwa disain penelitian merupakan plan of action that links the philosophical assumptions to specipic methods. Penelitian ini dibuat dengan dalam 3 tahapan seperti dibawah ini.

1. Tahapan perencanaan pembelajaran dimana indikatornya adalah komponen silabus dan RPP.

2. Tahapan pelaksanaan pembelajaran dimana indikatornya adalah kegiatan awal,kegiatan inti dan kegiatan penutup.

3. Tahapan hasil penilaian dimana indikatornya adalah penilaian proses pembelajaran dan hasil belajar.

Berdasarkan pemilihan instrumen penelitian dan dasar teori yang telah dikemukakan, maka 
instrumen penelitian yang digunakan dalam penelitian ini yaitu: pedoman observasi, wawancara terbuka dan dokumentasi.

Pemeriksaan Keabsahan Data (Triangulasi) 1. Kriteria Keabsahan Data

Untuk menetapkan keabsa-han (trustworthiness) data diperlukan teknik pemeriksaan. Pelaksanaan teknik pemeriksaaan didasarkan atas sejumlah kriteria tertentu. Ada empat kriteria yang digunakan yaitu derajat kepercayaaan (Credibelity), keteralihan (transferability), Kebergantungan (dependability). Dan kepastian (Confirmability).

\section{Pemeriksaan Keabsahan Data}

(Triangulasi)

Trianggulasi adalah teknik pemeriksaan keabsahan data yang memanfaatkan sesuatu yang lain di luar data itu untuk keperluan pengecekan atau sebagai pembanding terhadap data itu. enzim (dalam Moleong, 1994) membedakan empat macam trianggulasi sebagi teknik pemeriksaaan yangmemanfaatkan sumber, metode, penyidik dan teori. Trianggulasi dengan sumber berarti membandingkan dan mengecek balik derajat kepercayaan suatu informasi yang diperoleh melalui waktu dan alat yang berbeda dalam metode kualitatif tersebut dapat dicapai melalui:

a) Membandingkan data hasil pengamatan dengan data hasil wawancara,

b) Membandingkan apa yang dikatakan orang didepan umum dengan apa yang dikatakanya secara pribadi,

c) membandingkan apa yang dikatakan orang-orang tentang situasi penelitian dengan apa yang dikatakanya sepanjang waktu,

d) membandingkan keadaan dan prespektif seseorang dengan berbagai pendapat dan pandangan orang seperti rakyat biasa, orang yang berpendidikan menegah atau tinggi, orang berada, orang pemerintahan;

e) Membandingkan hasil wawancara dengan isi suatu dokumen yang berkaitan dengan penelitian.

\section{HASIL DAN PEMBAHASAN}

Kompetensi Profesional Guru

Dalam sistem pendidikan nasional 
kita, eksistensi guru sangat penting, guru merupakan jabatan atau profesi yang memerlukan keahlian khusus sebagai guru. Menurut UU No. 14 tahun 2005 tentang Guru dan Dosen, guru adalah pendidik profesional dengan tugas utama mendidik, mengajar, membimbing, mengarahkan, melatih, menilai, dan mengevaluasi peserta didik pada pendidikan anak usia dini di jalur pendidikan formal, pendidikan dasar,dan pendidikan menengah (Pasal 1 ayat 1). Profesional adalah pekerjaan atau kegiatan yang dilakukan oleh seseorang dan menjadi sumber penghasilan kehidupan yang memerlukan keahlian, kemahiran, atau kecakapan yang memenuhi standar mutu atau norma tertentu serta memerlukan pendidikan profesi (Pasal 1 ayat 4).

\section{Selanjutnya,} menurut Undangundang No. 14 tahun 2005 tentang Guru dan Dosen, kompetensi profesional adalah "kemampuan penguasaan materi pelajaran secara luas dan mendalam". Surya (2003:

138) mengemukakan kompetensi profesional adalah berbagai kemampuan yang diperlukan agar dapat mewujudkan dirinya sebagai guru profesional. Kompetensi profesional meliputi kepakaran atau keahlian dalam bidangnya yaitu penguasaan bahan yang harus diajarkannya beserta metodenya, rasa tanggung jawab akan tugasnya dan rasa kebersamaan dengan sejawat guru lainnya.

Berdasarkan uraian di atas, maka kompetensi profesional guru dalam penelitian ini adalah kemampuan yang ditunjukkan oleh guru dalam berpikir logis, dapat menyederhanakan keabstrakan, mendorong peserta didik untuk percaya diri dan berjuang yang tinggi, menggunakan bahasa simbol, meningkatkan daya abstraksi dan mendorong peserta didik senang dalam melakukan pekerjaan .

Kompetensi profesional tersebut terbagi menjadi 3 yaitu; (1) kompetensi merencanakan pembelajaran; kompetensi melaksanakan pembelajaran; dan (3) kompetensi menilai pembelajaran. Ketiga kompetensi profesional guru tersebut akan diuraikan berikut ini.

$$
\text { Pada bagian ini }
$$
dideskripsikan temuan penelitian evaluasi atas kompetensi profesional guru dalam mengelola pembelajaran 
IPA di SD Muhammadiyah seKabupaten Gorontalo.

\section{Kompetensi Profesional Guru dalam Merencanakan Pembelajaran}

Tugas-tugas guru dalam perencanaan pembelajaran meliputi kemampuan dalam memahami tujuan pembelajaran, melakukan analisis pembelajaran, mengenali perilaku peserta didik, mengidentifikasi karakteristik peserta didik, merumuskan tujuan pembelajaran, mengembangkan materi pelajaran, mengembangkan media dan metode pembelajaran, menerapkan sumber-sumber pembelajaran, mengkoordinasikan segala faktor pendukung, mengembangkan dan melakukan penilaian awal terhadap rencana pembelajaran, merevisi pembelajaran, dan melakukan penilaian akhir terhadap rencana pembelajaran. (Rusman, 2009: 336).

Dengan demikian, perencanaan pembelajaran dapat diartikan sebagai suatu rangkaian yang saling berhubungan dan saling menunjang antara berbagai unsur atau komponen yang ada di dalam pembelajaran. Dengan kata lain, perencanaan pembelajaran merupakan suatu proses mengatur, mengkoordinasikan, dan menetapkan unsur-unsur atau komponenkomponen pembelajaran. Unsur atau komponen yang dimaksud adalah: (1) kemana pembelajaran tersebut akan diarahkan?; (2) apa yang harus dibahas dalam proses pembelajaran tersebut?; (3) bagaimana cara melakukannya?; (4) bagaimana cara mengetahui berhasil atau tidaknya proses pembelajaran tersebut?

Berdasarkan penjelasan di atas, maka dapat disimpulkan bahwa pada kompetensi professional guru dalam merencanakan pembelajaran pada hakikatnyaadalah kemampuan yang harus dimiliki guru dalam menguasai bahan ajar.Dalam merencanakan pembelajaran, guru memerlukan perangkat pembelajaran yaitu silabus dan RPP.

Perencanaan pembelajaran adalah suatu rangkaian yang saling berhubungan dan saling menunjang antara berbagai unsure atau komponen yang ada dalam pembelajaran.

Pada kompetensi perencanaan pembelajaran terdapat beberapa fokus evaluasi yaitu pengembangan silabus dan RPP, pengkajian standar isi, dan 
pembuatan silabus dan RPP. Tingkat pencapaian persentase pada perencanaaan pembelajaran khususnya pada silabus dan RPP pada hampir semua sekolah mempunyai persentase pencapaian rata-rata di atas $75 \%$ dan berada dalam kategori baik. Hanya saja pada beberapa sekolah masih memperlihatkan tingkat pencapaian $<75 \%$.

\section{Kompetensi Profesional Guru dalam Melaksanakan Pembelajaran}

Kegiatan pembelajaran di kelas adalah inti penyelenggaraan pendidikan yang ditandai oleh adanya kegiatan pengelolaan kelas, penggunaan media dan sumber belajar, dan penggunaan metode serta strategi pembejaran.Semua tugas tersebut merupakan tugas dan tanggung jawab guru yang secara optimal dalam pelaksanaanya menuntut kemampuan guru.

Kemampuan dalam pelaksanaan pembelajaran yang perlu dikuasai guru di samping pengelolaan kelas adalah menggunakan media dan sumber belajar.Media adalah segala sesuatu yang dapat digunakan untuk menyalurkan pesan (materi pembelajaran), merangsang pikiran, perasaan, perhatian, dankemampuan peserta didik, sehingga dapat mendorong proses pembelajaran. Tatapi kemampuan guru di sini lebih ditekankan padapenggunaan objek nyata yang ada di sekitar sekolahnya. Dalam kenyataan di lapangan guru dapat memanfaatkan media yang sudahada (by utilization) seperti globe, peta, gambar dan sebagainya, atau gurudapat mendesain media untuk kepentingan pembelajaran (by design) sepertimembuat media foto, film, pembelajaran berbasis komputer, dan sebagainya.

Berdasarkan penjelasan di atas, maka kompetensi profesional guru dalam melaksanakan pembelajaran adalah kemampuan yang harus dimiliki guru dalam pengelolaan dan penggunaan media dalam proses pembelajaran di kelas.

Kompetensi profesional guru dalam melaksanakan pembelajaran adalah kemampuan yang harus dimiliki guru dalam pengelolaan dan penggunaan media dalam proses pembelajaran di kelas. Ketika dilakukan analisis secara kuantitatif dengan memperlihatkan pada tingkat persentase yang diperoleh hampir semua guru memiliki tingkat 
persentase $<75 \%$ dengan kategori cukup.

Hal ini perlu menjadi perhatian khusus bagi pihak terkait karena pelaksanaan pemebelajaran merupakan inti dari penyelenggaraan pendidikan itu sendiri.

\section{Kompetensi Profesional Guru dalam Menilai Pembelajaran}

Penilaian hasil belajar adalah kegiatan atau cara yang ditujukan untuk mengetahui tercapai atau tidaknya tujuan pembelajaran dan juga proses pembelajaran yang telah dilakukan. Pada tahap ini seorang guru dituntut memiliki kemampuan dalam menentukan pendekatan dan cara-cara evaluasi, penyusunan alat-alat evaluasi, pengolahan, dan penggunaan hasil evaluasi. Pendekatan atau cara yang dapat digunakan untuk melakukan evaluasi/ penilaian hasil belajar adalah melalui Penilaian Acuan Norma (PAN) dan Penilaian Acuan Patokan (PAP). PAN adalah cara penilaian yang tidak selalu tergantung pada jumlah soal yang diberikan atau penilaian dimasudkan untuk mengetahui kedudukan hasil belajar yang dicapai berdasarkan norma kelas. Nilai yang diperoleh peserta didik tergantung pada seberapa jauh tujuan yang tercermin dalam soal-soal tes yang dapat dikuasai peserta didik. Nilai tertinggi adalah nilai sebenarnya berdasarkan jumlah soal tes yang dijawab dengan benar oleh peserta didik. Untuk melakukan evaluasi yaitu melalui PAN dan PAP. Adapun alat evaluasi meliputi tes tertulis, tes lisan dan tes perbuatan. Berdasarkan pada analisis hasil observasi, diperoleh persentase rata-rata $<75 \%$ dengan kategori cukup. Hanya satu orang guru saja yang melaksanakan proses penilaian dengan sangat baik yakni sekitar $95,24 \%$.

Hakikat Pembelajaran IPA

Pembelajaran IPA merupakan salah satu aspek pendidikan dengan menggunakan IPA sebagai alatnya untuk mencapai tujuan pendidikan pada umunya dan Pembelajaran IPA pada khususnya. Dalam Pembelajaran IPA, antara IPA sebagai "produk" dan IPA sebagai "proses" hendaknya mendapat penekanan yang seimbang. Selama ini, tampaknya pengajaran IPA di sekolah memberi tekanan yang jauh lebih besar pada IPA sebagai "produk" daripada IPA sebagai "proses". Pendidikan IPA pada hakekatnya tidak hanya dapat digunakan untuk membekali subjek 
didik dengan pengetahuan dan keterampilan proses, tetapi juga dapat digunakan untuk menanamkan sikap dan nilai. Jadi, pembelajaran IPA juga dapat digunakan sebagai wahana klarifikasi nilai, yang selama ini kurang mendapat perhatian para guru dan peserta didik

Merujuk pada pengertian IPA itu, maka dapat disimpulkan bahwa hakikat IPA meliputi empat unsur utama yaitu:

1) sikap: rasa ingin tahu tentang benda, fenomena alam, makhluk hidup, serta hubungan sebab akibat yang menimbulkan masalah baru yang dapat dipecahkan melalui prosedur yang

benar; IPA bersifat open ended;

2) proses: prosedur pemecahan masalah melalui metode ilmiah; metode ilmiah meliputi penyusunan hipotesis, perancangan eksperimen atau percobaan, evaluasi, pengukuran, dan penarikan kesimpulan;

3) produk: berupa fakta, prinsip, teori, dan hukum;

4) aplikasi: penerapan metode ilmiah dan konsep IPA dalam kehidupan seharihari.

\section{Kesimpulan}

Berdasarkan temuan-temuan dan pembahasan hasil evaluasi pelaksanaan kompetensi profesional guru dalam pembelajaran IPA di SD Muhammadiyah se-Kabupaten Gorontalo, maka dapat peneliti simpulkan bahwa:

1. Kompetensi profesional guru dalam menyusun perencanaan pembelajaran IPA di SD seKabupaten Gorontalo secara umum sudah baik. Hanya pada beberapa orang guru yang kurang dalam merencanakan pembelajaran.

2. Kompetensi profesional guru dalam melaksanakan pembelajaran yang dalam hal ini adalah kualitas pengelolaan kelas masih kurang optimal. Oleh sebab itu, perlu adanya upaya-upaya perbaikan untuk peningkatan mutu pembelajaran.

3. Kompetensi profesional guru dalam menilai pembelajaran secara umum masih kurang dan butuh perbaikan. Masih banyak guru yang kurang optimal dalam melaksanakan penilai

\section{Saran}


1. Kepada pemerintah agar senantiasa memperhatikan kualitas pendidikan terutama kualitas pendidik dalam hal penguasaan kompetensi baik kompetensi pedagogik, profesional, sosial maupun kompetensi kepribadian.

2. Harus dilakukan lagi training atau pelatihan-pelatihan dalam hal pembuatan silabus dan RPP yang disesuaikan dengan aturan penulisan silabus dan RPP sesuai dengan yang telah ditetapkan oleh pembuat kebijakan pendidikan.

3. Perlu dilaksanakan kegiatankegiatan peningkatan mutu pembelajaran seperti kegiatan KKG yang dilakukan secara rutin, pelaksanaan supervisi dan seminar pendidikan.

\section{Daftar Pustaka}

Afandi, Akbar. 2009. Kemampuan Guru dalam proses Belajar Mengajar. Bandung: Remaja Rosda Karya

Aryan. 2007. Kompetensi Profesional dan Kompetensi Akademik Guru Matematika. (http:www.
Kompetensi Profesional dan

Kompetensi Akademik Guru

Matematika $<$ Anugerah 'Jang

Guru'.htm) diakses 20 Juli 2012

Creswell. J.W. (2009). Research Design

Qualitative, Quantitative, and

Mixed Methods Approaches, 2nd

ed. Thousand Oaks, CA : Sage

Publications.

Deppennas. 2008. Penilaian Kinerja

Guru. Kompetensi Evaluasi

Pendidikan 04-B3. Jakarta :

\section{PMPTK}

Indrawati, Yuliani. 2006. Faktor-Faktor Yang Mempengaruhi Kinerja Guru Matematika Dalam Pelaksanaan Kurikulum Berbasis Kompetensi ( KBK) Pada Sekolah Menengah Atas Kota Palembang. Tesis.

Kemenpennas. 2010. Pedoman

Pelaksanaan Penilaian Kinerja

Guru. Jakarta : PNPTK Mulyasa, E., (2003). Kurikulum Berbasis Kompetensi: Konsep, Karakteristik, dan Implementasi. Bandung: PT Remaja Rosdakarya 
Nasution, S, 2000, Penelitian Ilmiah, Jakarta : Penerbit Bumi Aksara.

Patilima, Hamid. (2007). Metode Penelitian Kualitatif. Bandung : Alfabeta.

Rusman. 2009. Manajemen Kurikulum.

Edisi 2. Jakarta: Rajawali Press.

Sugiyono. 2009. Statistik Untuk Penelitian. Bandung: CV. Alfabeta.

Syah, Muhibbin. (2000). Psikologi Pendidikan dengan Pendekatan Baru. Bandung: PT Remaja Rosdakarya.

Uno, Hamzah B. 2008. Profesi Kependidikan. Jakarta: PT Bumi Aksara 